\title{
Diel changes in endolymph aragonite saturation rate and mRNA expression of otolith matrix proteins in the trout otolith organ
}

\author{
Yasuaki Takagi ${ }^{1, *}$, Hidekazu Tohse ${ }^{1,2}$, Emi Murayama $^{2,3}$, Tsuyoshi Ohira $^{2,4}$, \\ Hiromichi Nagasawa ${ }^{2}$
}

\author{
${ }^{1}$ Graduate School of Fisheries Sciences, Hokkaido University, Minato, Hakodate, Hokkaido 041-8611, Japan \\ ${ }^{2}$ Graduate School of Agricultural and Life Sciences, The University of Tokyo, Yayoi, Bunkyo-ku, Tokyo 113-8657, Japan \\ ${ }^{3}$ Present address: Unité Macrophages et Développement de l'Immunité, Département de Biologie du Développement, \\ Institut Pasteur, 25 rue du Dr Roux, 75724 Paris cedex 15, France \\ ${ }^{4}$ Present address: Japan International Research Center for Agricultural Sciences, Owashi, Tsukuba, \\ Ibaraki 305-8686, Japan
}

\begin{abstract}
In the teleost fish otolith, the alternate deposition of $\mathrm{CaCO}_{3}$-rich and protein-rich layers results in the formation of daily increments. In order to clarify the mechanism of daily increment formation, a precise understanding of the relationship between ionic and organic controls of otolith growth is essential. In the present study, we studied diel variations in the aragonite saturation rate $\left(S_{\mathrm{a}}\right)$ of the endolymph and the mRNA expression of 2 major otolith matrix proteins, OMP-1 and otolin1 , in the saccular tissue. A new technique for simultaneously quantifying endolymph $S_{\text {a }}$ and mRNA expression in the saccular tissue from an individual rainbow trout was developed. Endolymph $\mathrm{Ca}^{2+}$ levels, $\mathrm{CO}_{2}$ partial pressure $\left(P_{\mathrm{CO}_{2}}\right)$ and $\mathrm{pH}$ were simultaneously measured using an automatic $\mathrm{pH} / \mathrm{gas} /$ electrolyte analyzer, and the $S_{\mathrm{a}}$ was calculated. Total RNA was isolated from sacculi of individual fish after the endolymph was obtained. cDNAs were synthesized and used to quantify OMP-1 and otolin-1 mRNA expression levels by real-time PCR. Significant diel variations were observed in endolymph pH and $P_{\mathrm{CO}_{2}}$ levels in an antiphasic manner. Endolymph $S_{\mathrm{a}}$ did not exhibit significant diel variations and was maintained at a value of more than 2.0, indicating that the endolymph was kept supersaturated with respect to aragonite during the day-night cycle. Expression of otolin-1 mRNA had apparent diel variations with high levels at night, whereas that of OMP-1 mRNA was almost constant. These data strongly suggest an organic control of daily increment formation in the otolith. The most probable candidate protein for daily increment formation is otolin-1.
\end{abstract}

KEY WORDS: Calcification · mRNA expression $\cdot$ Endolymph · Daily increment · Aragonite $\cdot$ Otolith · Rainbow trout Resale or republication not permitted without written consent of the publisher

\section{INTRODUCTION}

Teleost fish otoliths are calcified concretions composed of organic matrices and calcium carbonate aragonite polycrystals (cf. Campana \& Neilson 1985, Campana 1999). Since Pannela (1971) described the occurrence of daily increments in otolith microstructure, otoliths have been used as determinants of dailyage in both larval and juvenile teleost fishes. Conse- quently, a large number of publications are dedicated to the use of otolith microstructures as a key for clarifying the population dynamics and life histories of teleost fishes. However, fundamental research on the mechanisms of otolith formation is insufficient and a great deal remains unknown.

Otolith microincrements consist of alternately deposited light and dark bands observed under transmitted light. The light band is generally called the L-zone, 
and the dark one is referred to as the D-zone (Kalish et al. 1995). Morphological examinations have revealed that the D-zones contain more organic matrices and less calcium carbonate relative to the L-zones (Mugiya \& Muramatsu 1982, Watabe et al. 1982, Morales-Nin 1987); therefore, the alternate manner in which the deposition of mineral-rich and organic-matrix-rich layers occurs is manifested as daily increments. Indeed, Mugiya (1987) reported the discrete antiphasic diel cycles of ${ }^{45} \mathrm{Ca}$ and ${ }^{3} \mathrm{H}$-glutamic-acid uptake into the otoliths in the rainbow trout in vitro and suggested that the daily increments of otoliths were formed by the antiphasic deposition of calcium and organic matrices. Daily variations in otolith calcification have also been demonstrated in the goldfish (Mugiya et al. 1981, Tohse \& Mugiya 2002) and in the Atlantic salmon (Wright et al. 1992).

The mechanism of these diel variations in otolith calcification and the deposition of the organic matrix is unknown. The otolith can be defined as acellular tissue that grows in an inner ear sacculus filled with endolymph. Consequently, endolymph must contain all the precursors required for otolith development, and the physicochemical characteristics of this fluid may affect otolith growth. The aragonite saturation rate $\left(S_{\mathrm{a}}\right)$ of endolymph is considered to be one of the candidates that regulates otolith calcification, since aragonite precipitation rate from a dilute solution has been demonstrated to correlate strongly with the $S_{\mathrm{a}}$ of the solution in a non-biological system (Romanek et al. 1991). Conversely, variations in the synthesis, secretion and endolymph concentration of the matrix proteins probably lead to fluctuations in the matrix deposition onto the otolith. The otolith matrix proteins may also affect otolith calcification, because organic matrices in biominerals have been reported to affect mineral deposition in general (Wheeler \& Sikes 1984, Addadi \& Weiner 1985, Belcher et al. 1996, Falini et al. 1996), and because otolith matrix proteins are known to interact with $\mathrm{Ca}$ or $\mathrm{CaCO}_{3}$ (Baba et al. 1991, Wright 1991, Asano \& Mugiya 1992, Sasagawa \& Mugiya 1996, Borelli et al. 2001, Murayama 2002).

The $S_{\mathrm{a}}$ is a function of the chemical composition of the solution. The first determination of the endolymph $S_{\mathrm{a}}$ in a single fish species based on the direct quantification of endolymph chemical composition was performed by Takagi (2002) in the rainbow trout. He reported that trout endolymph was supersaturated with respect to aragonite. Previous studies have also partially determined endolymph chemical compositions (Enger 1964, Mugiya 1966, Fänge et al. 1972, Watanabe \& Miyamoto 1973, Mugiya \& Takahashi 1985, Kalish 1991, Payan et al. 1997, 1998, 1999, Takagi 1997, Gauldie \& Romanek 1998, Edeyer et al. 2000, Borelli et al. 2003), with some authors reporting diel changes in endolymph composition. Although these data suggest that the diel variations in the endolymph composition generate daily rhythm of otolith calcification through the fluctuations of $S_{\mathrm{a}}$, no direct determination of diel variations in endolymph $S_{\mathrm{a}}$ has been conducted.

Otolith organic matrix proteins are synthesized in the epithelial cells of the sacculus and secreted into the endolymph (Takagi \& Takahashi 1999, Takagi 2000, Takagi et al. 2000, Murayama et al. 2002, 2004). However, otolith matrix proteins seem to constitute rather minor components of the endolymph proteins (Takagi \& Takahashi 1999, Borelli et al. 2001); thus, reported diel variations in the concentrations of total endolymph proteins (Edeyer et al. 2000, Borelli et al. 2003) may not be reasonably correlated to the diurnal rhythm in otolith matrix deposition. The only study that has dealt with the endolymph concentrations of otolith matrix proteins is the report of Borelli et al. (2003), in which antibodies were raised against the acetic-acid-soluble fraction of the otolith matrix proteins in the rainbow trout. Using densitometric analysis of Western blot samples of the endolymph, these authors demonstrated that the 2 bands that reacted with the antibody were more concentrated during the day than at night. However, no direct quantification of the synthesis and secretion of otolith proteins has been undertaken to date.

Recently, we cloned 2 cDNAs of the otolith matrix protein, OMP-1 and otolin-1, from salmonid fishes and demonstrated their specific expressions in the otolith organ (Murayama et al. 2000, 2002). Immunohistochemical studies using specific antibodies against OMP-1 and otolin-1 proteins, respectively, revealed that the differences in the densities of these proteins are responsible for the development of the concentric ring-like structures in the otolith matrix (Murayama 2002, Murayama et al. 2002, 2004).

In the present study, we studied diel variations in the endolymph $S_{\text {a }}$ and the mRNA expression of OMP-1 and otolin-1 in the saccular tissue. A new technique for simultaneously quantifying endolymph $S_{\mathrm{a}}$ and mRNA expression in the saccular tissue from an individual rainbow trout was developed.

\section{MATERIALS AND METHODS}

Fish and maintenance. Rainbow trout Oncorhynchus mykiss, weighing about 800 to $1000 \mathrm{~g}$, were obtained from a local farm in Hokkaido, Japan. They were maintained in outdoor tanks with continuous supplies of fresh water and fed to satiation with commercial trout pellets once a day at 13:00 h. Water temperature on the days of sampling fluctuated daily between 12 and $16.5^{\circ} \mathrm{C}$. Fish were acclimatized to experimental 
conditions for about $3 \mathrm{wk}$ prior to initiation of sampling.

Sampling of blood, endolymph and sacculi. At 09:00, 15:00 and 21:00 h on August 27 and at 03:00 and 09:00 h on August 28, 2003, blood, endolymph and saccular tissue from 9 to 12 fish were sampled as described below. Our preliminary results suggested that frequent repetition of sampling at short time intervals $(<15 \mathrm{~min})$ was stressful to the remaining fish in the tank. Fish were, therefore, kept at rest for at least $5 \mathrm{~h}$ before the next sampling. Fish were deeply anaesthetized in a $0.1 \%$ solution of 2-phenoxyethanol, and blood was taken from the caudal vessels without touching the air using a heparinized syringe. The fish were then decapitated, and the blood samples and heads kept on ice until further processing. Both left and right sacculi were sampled and endolymph was collected as previously described (Takagi 2002). Briefly, the sacculi were immersed in liquid paraffin to avoid any contact of endolymph with the air. The endolymph was then sucked into capillary tubes with the liquid paraffin, sealed at one end with a capillary sealer, and centrifuged for $3 \mathrm{~s}$ at $10000 \times g \cdot \mathrm{Ca}^{2+}, \mathrm{CO}_{2}$ partial pressure $\left(P_{\mathrm{CO}_{2}}\right)$ and $\mathrm{pH}$ levels were measured immediately after centrifugation as described below. Pooled samples from the left and right sacculi of each individual were sufficient to assay endolymph chemicals. Once endolymph had been sampled, both sacculi were immediately frozen in liquid nitrogen and kept at under $-80^{\circ} \mathrm{C}$ until the extraction of RNA.

Determination of blood and endolymph chemicals. Blood $\mathrm{Ca}^{2+}\left(\mathrm{mmol} \mathrm{l}{ }^{-1}\right), \mathrm{Na}^{+}\left(\mathrm{mmol} \mathrm{l}{ }^{-1}\right), P_{\mathrm{CO}_{2}}$ (torr) and $\mathrm{pH}$ levels, and endolymph $\mathrm{Ca}^{2+}, P_{\mathrm{CO}_{2}}$ and $\mathrm{pH}$ levels were measured using an automatic $\mathrm{pH} / \mathrm{gas} / \mathrm{electrolyte}$ analyzer (Model 348, Chiron Diagnostics Limited). Plasma and endolymph $\mathrm{HCO}_{3}{ }^{-}$and $\mathrm{CO}_{3}{ }^{2-}$ levels (mmol $\mathrm{l}^{-1}$ ) were obtained using the Henderson-Hasselbalch equation. The aragonite saturation rate $\left(S_{\mathrm{a}}\right)$ of the endolymph was calculated as follows:

$$
S_{\mathrm{a}}=\sqrt{\frac{\left(\mathrm{Ca}^{2+}\right)\left(\mathrm{CO}_{3}^{2-}\right)}{K_{S, \mathrm{a}}^{0}}}
$$

where $\left(C_{i}\right)$ is the activity of ionic species $i$, and $K_{S, a}^{0}$ is the thermodynamic solubility product of aragonite. When $S_{a}$ $<1, S_{\mathrm{a}}=1$ and $S_{\mathrm{a}}>1$, the solution is respectively undersaturated, at equilibrium and supersaturated with respect to aragonite. A more detailed method of calculation is described in Takagi (2002).

Quantification of mRNA expression for OMP-1 and otolin-1 in saccular tissue. One sacculus per fish was used to quantify mRNA expression of OMP-1 and otolin-1. Total RNA was prepared from individual sacculi using Isogen (Nippon gene) according to the manufacturer's instructions. After DNase I (TaKaRa) treatment, 30 ng of each total RNA was reverse-transcribed using a First-Strand cDNA Synthesis kit (Amersham Biosciences) with oligo-d $(\mathrm{T})_{18}$ primer. Using 1/100 aliquots of each cDNA as a template, quantitative PCR was performed using gene-specific primers and Taq$\mathrm{Man}^{\mathrm{TM}}$ probes depicted in Table 1 . The reaction mixture $(50 \mu \mathrm{l})$ contains $1 \times$ QPCR mix (Absolute ${ }^{\mathrm{TM}} \mathrm{QPCR}$ ROX Mix, Advanced Biotechnologies), $900 \mathrm{nM}$ of each primer, $450 \mathrm{nM}$ of each probe, and first-strand cDNA. The conditions for PCR included an initial step at $95^{\circ} \mathrm{C}$ for $15 \mathrm{~min}$, followed by 40 cycles at $95^{\circ} \mathrm{C}$ for $15 \mathrm{~s}$ and $58^{\circ} \mathrm{C}$ for $1 \mathrm{~min}$. Amplification plots were collected using a sequence detection system (ABI PRISM 7700 Sequence Detection System, Applied Biosystems).

Detected copy numbers of OMP-1 and otolin-1 mRNAs were standardized against $\beta$-actin mRNA. Expression levels of $\beta$-actin mRNA were almost constant for the duration of the experiment.

Statistics. Data are presented as means and standard errors. To assess the significance of the variations, data were analysed using the Kruskal-Wallis test. When a significant difference was detected by the KruskalWallis test, significance between 2 selected groups was tested using the Mann-Whitney $U$-test. The relationships of $\mathrm{pH}, P_{\mathrm{CO}_{2}}$ and ion levels between endolymph and blood were analysed using a Spearman rank correlation test. StatView software (SAS Institute) was used for analyses and statistical significance was taken as $\mathrm{p}<0.05$.

\section{RESULTS}

\section{Endolymph $\mathrm{pH}, P_{\mathrm{CO}_{2}}, S_{\mathrm{a}}$ and ion levels}

Endolymph $\mathrm{Ca}^{2+}$ levels were observed to vary significantly depending on the sampling time (Fig. 1A). Endolymph $\mathrm{pH}$ levels exhibited significant diel fluctuations with high values observed at night (Fig. 1B). Conversely, 

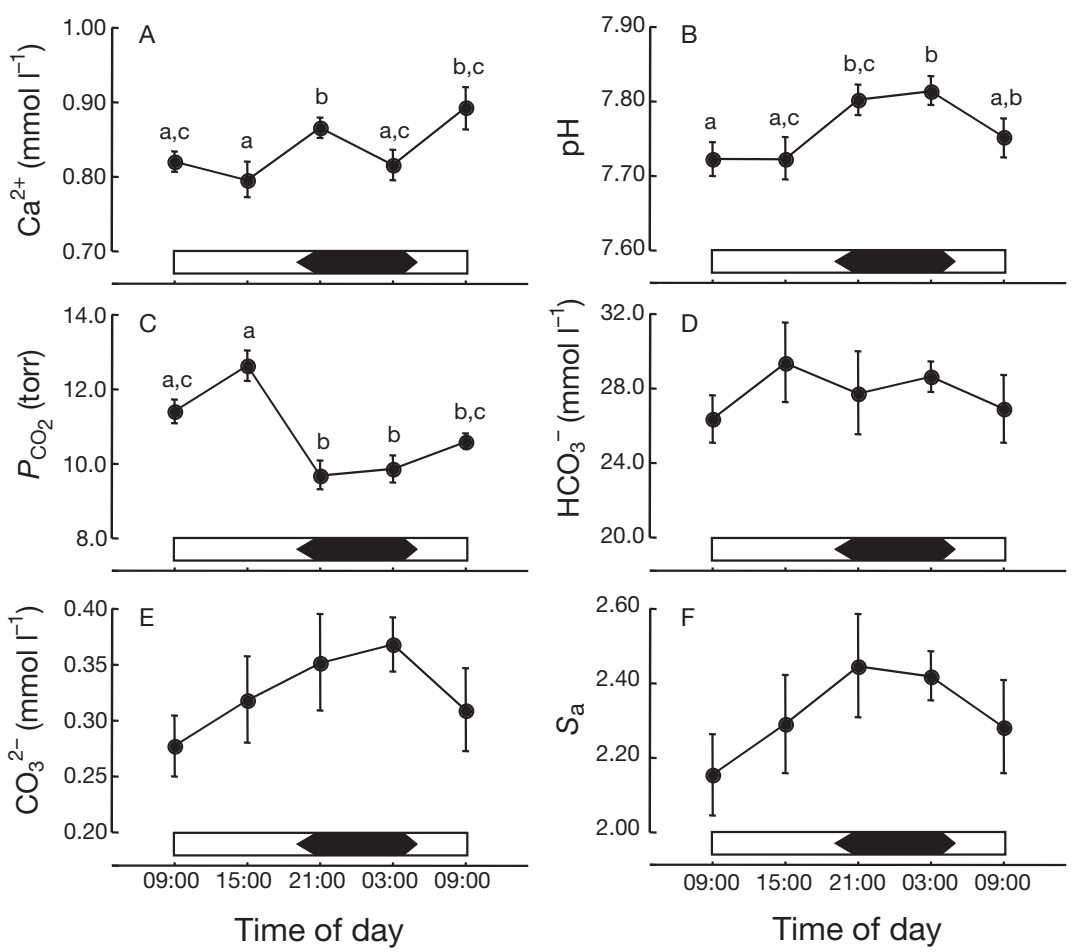

Fig. 1. Oncorhynchus mykiss. Diel variations in the endolymph parameters. (A) $\mathrm{Ca}^{2+}$, (B) $\mathrm{pH}$, (C) $P_{\mathrm{CO}_{2}}$ (D) $\mathrm{HCO}_{3}{ }^{-}$, (E) $\mathrm{CO}_{3}{ }^{2-}$, (F) aragonite saturation rate $\left(S_{\mathrm{a}}\right)$. Each point and bar represent mean and SE. Number of samples measured: 9 to 12. Significant variations were observed in the levels of $\mathrm{Ca}^{2+}, \mathrm{pH}$ and $P_{\mathrm{CO}_{2}}$ (Kruskal-Wallis test, $\mathrm{p}<0.05$ ), and data not sharing a common letter are significantly different (Mann-Whitney $U$-test, $\mathrm{p}<0.05$ )
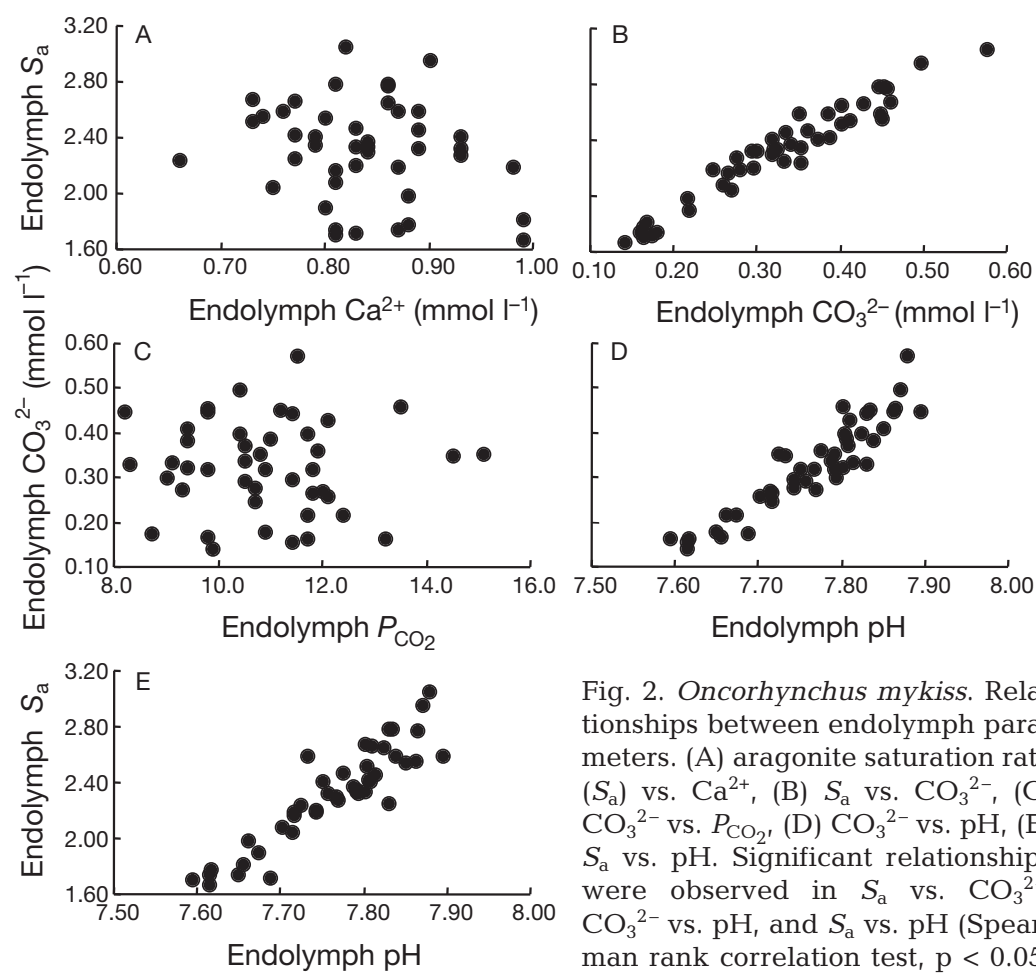

Fig. 2. Oncorhynchus mykiss. Relationships between endolymph parameters. (A) aragonite saturation rate $\left(S_{\mathrm{a}}\right)$ vs. $\mathrm{Ca}^{2+},(\mathrm{B}) \mathrm{S}_{\mathrm{a}}$ vs. $\mathrm{CO}_{3}^{2-},(\mathrm{C})$ $\mathrm{CO}_{3}{ }^{2-}$ vs. $P_{\mathrm{CO}_{2}}$ (D) $\mathrm{CO}_{3}{ }^{2-}$ vs. $\mathrm{pH},(\mathrm{E})$ $S_{\text {a }}$ vs. pH. Significant relationships were observed in $S_{\mathrm{a}}$ vs. $\mathrm{CO}_{3}{ }^{2-}$, $\mathrm{CO}_{3}{ }^{2-}$ vs. pH, and $S_{\mathrm{a}}$ vs. pH (Spearman rank correlation test, $\mathrm{p}<0.05$ )
$P_{\mathrm{CO}_{2}}$ levels were significantly higher during the day (Fig. 1C). No significant variations were observed in $\mathrm{HCO}_{3}^{-}$concentrations (Fig. 1D). Levels of $\mathrm{CO}_{3}{ }^{2-}$ exhibited diel fluctuations, with relatively higher values observed at night, but the differences were not statistically significant (Fig. 1E). Endolymph $S_{\mathrm{a}}$ did not exhibit significant diel variations and was maintained at a value of more than 2.0 , indicating that the endolymph was kept supersaturated with respect to aragonite during the day-night cycle (Fig. 1F).

Since $\mathrm{pH}, \mathrm{Ca}^{2+}$ concentrations, $P_{\mathrm{CO}_{2}}$ levels, $\mathrm{CO}_{3}{ }^{2-}$ concentrations, and the $S_{\mathrm{a}}$ of the endolymph were obtained from individual fish, the relationships between these factors could be analyzed (Fig. 2). $S_{\text {a }}$ correlated significantly with $\mathrm{CO}_{3}{ }^{2-}$ levels, but not with $\mathrm{Ca}^{2+}$ concentrations (Fig. 2A,B). $\mathrm{CO}_{3}{ }^{2-}$ levels were closely related to $\mathrm{pH}$, but not to $P_{\mathrm{CO}_{2}}$ levels (Fig. 2C,D). Consequently, a linear correlation was observed between $S_{\mathrm{a}}$ and $\mathrm{pH}$ (Fig. 2E).

\section{Plasma $\mathrm{pH}, \boldsymbol{P}_{\mathrm{CO}_{2}}$ and ion levels}

Significant diel fluctuations were observed in all of the plasma parameters assayed (Fig. 3). Plasma Ca ${ }^{2+}$ and $P_{\mathrm{CO}_{2}}$ levels were highest during the day, decreased significantly during the night and returned to initial levels at 09:00 $\mathrm{h}$ of Day 2 (Fig. 3A,D). In contrast, $\mathrm{pH}, \mathrm{HCO}_{3}{ }^{-}$ and $\mathrm{CO}_{3}{ }^{2-}$ levels had minimum values at 15:00 h, which then gradually increased to the initial levels (Fig. 3C,E,F). Plasma $\mathrm{Na}^{+}$concentrations were significantly higher at 09:00 h of Day 2 (Fig. 3B).

The relationships of $\mathrm{pH}$ levels, $P_{\mathrm{CO}_{2}}$ and ion concentrations between endolymph and plasma are shown in Fig. 4. A significant correlation was only observed between the $P_{\mathrm{CO}_{2}}$ levels in the endolymph and those in the plasma (Fig. 4C).

\section{Expression of OMP-1 and otolin-1 mRNAs}

Fig. 5 shows the diel variations in the expression of OMP-1 and otolin-1 mRNAs in the saccular tissue. The relative 

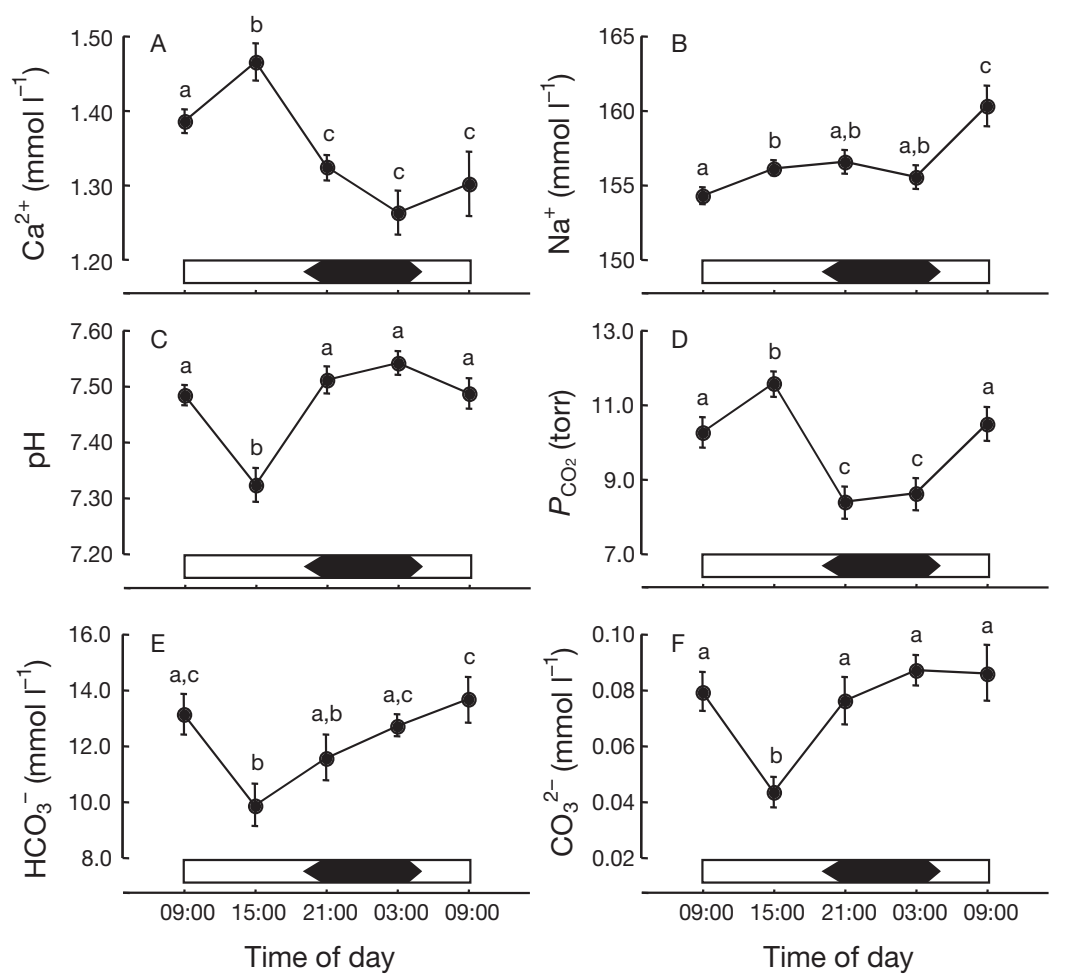

Fig. 3. Oncorhynchus mykiss. Diel variations in plasma parameters. (A) $\mathrm{Ca}^{2+}$, (B) $\mathrm{Na}^{+}$, (C) $\mathrm{pH}$, (D) $P_{\mathrm{CO}_{2}}$ (E) $\mathrm{HCO}_{3}{ }^{-}$, (F) $\mathrm{CO}_{3}{ }^{2-}$. Each point and bar represent mean and SE. Number of samples measured: 9 to 12. Significant variations were observed in all the parameters (Kruskal-Wallis test, $\mathrm{p}<0.05$ ), and data not sharing a common letter are significantly different (Mann-Whitney $U$-test, $\mathrm{p}<0.05$ )
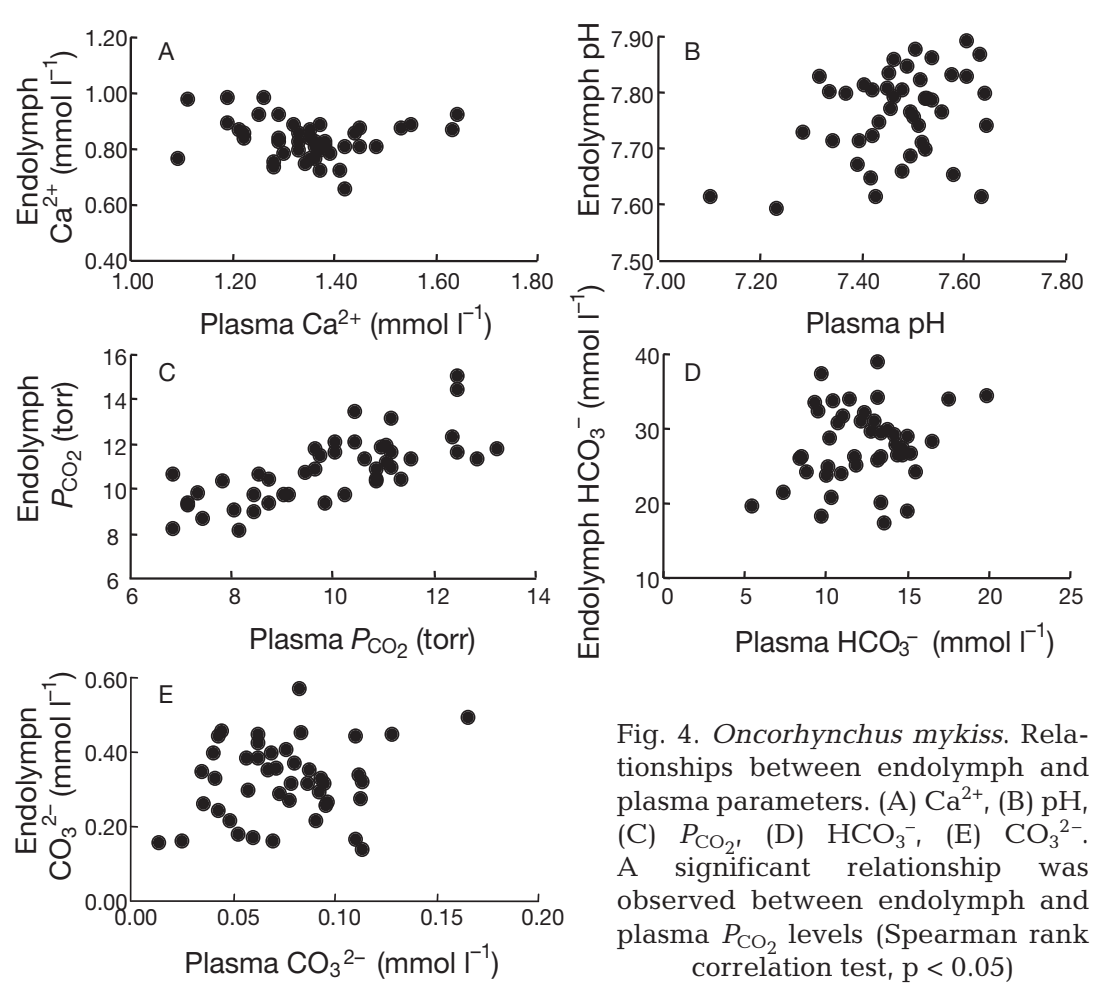

Fig. 4. Oncorhynchus mykiss. Relationships between endolymph and plasma parameters. (A) $\mathrm{Ca}^{2+}$, (B) $\mathrm{pH}_{1}$ (C) $P_{\mathrm{CO}_{2}}$ (D) $\mathrm{HCO}_{3}^{-}$, (E) $\mathrm{CO}_{3}{ }^{2-}$. A significant relationship was observed between endolymph and plasma $P_{\mathrm{CO}_{2}}$ levels (Spearman rank correlation test, $\mathrm{p}<0.05$ ) expression of OMP-1 mRNA to $\beta$-actin expression was around 0.2 ; it was almost constant during the day-night cycle and was maintained at levels that exceeded those observed for otolin-1 mRNA expression. The expression of otolin-1 mRNA exhibited significant diel changes with higher values recorded at night. During the day (between 09:00 and 15:00 h), the relative expression of otolin-1 mRNA was approximately 0.1 , half that observed for OMP-1 mRNA expression. At 21:00 h, however, expression was observed to increase markedly reaching a peak value of about 0.2 that was maintained until 03:00 h, before decreasing to approximately 0.1 at 09:00 h the next day.

\section{DISCUSSION}

The alternate deposition of mineralrich and organic-matrix-rich layers constructs daily increments in the teleost fish otolith (Mugiya \& Muramatsu 1982, Watabe et al. 1982, Morales-Nin 1987). In order to clarify the mechanism underlying the formation of daily increments, a thorough understanding of the relationship between ionic and organic controls of otolith growth is necessary. In the present study, we developed a technique to simultaneously quantify endolymph ionic composition and mRNA expression levels of otolith matrix proteins, OMP-1 and otolin-1, in the saccular tissue from an individual rainbow trout. From the quantified ionic composition, the aragonite saturation rate $\left(S_{\mathrm{a}}\right)$ of the endolymph was calculated. The results clearly showed (1) that the mRNA expression of otolin-1 exhibits a diel rhythm with higher expression occurring at night, and (2) that the saccular endolymph is supersaturated with respect to aragonite and that the saturation ratio is independent of the day-night cycle. This is the first study to simultaneously investigate the relationship between ionic and organic controls of otolith growth using data from individual fish.

The marked diel fluctuation in mRNA expression of otolin-1 indicates that the diel fluctuation reported for matrix 


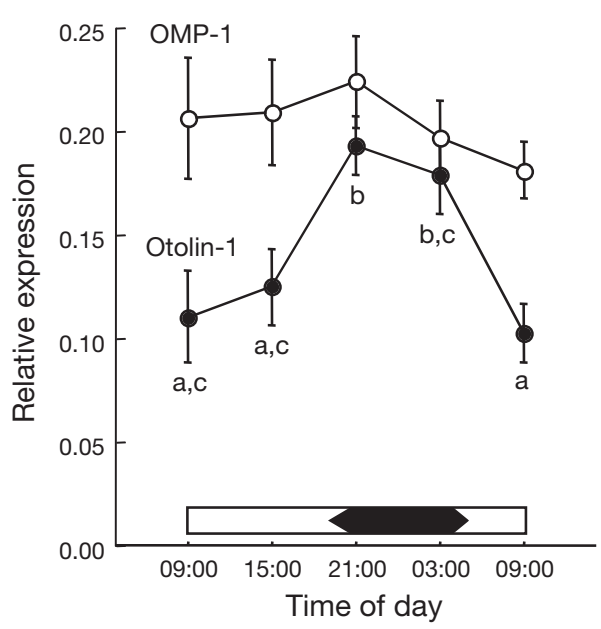

Fig. 5. Oncorhynchus mykiss. Diel variations in the expression of OMP-1 and otolin-1 mRNAs in saccular tissue Detected copy numbers of OMP-1 and otolin-1 mRNAs were standardized against $\beta$-actin mRNA. Each point and bar represent mean and SE. Number of samples measured: 9 to 12 . A significant variation was observed in the expression of otolin-1 mRNA (Kruskal-Wallis test, $\mathrm{p}<0.05$ ), and data not sharing a common letter are significantly different (MannWhitney $U$-test, $\mathrm{p}<0.05$ )

deposition in the otolith (Mugiya 1987) is regulated at the level of mRNA-expression of matrix protein. Otolin-1 is the most abundant protein contained in the EDTA-insoluble fraction of the otolith matrices and exhibits structural similarity with collagen types VIII and X (Murayama et al. 2002). Collagen types VIII and $\mathrm{X}$ are short-chain collagens known to form a 3-dimensional structure (Sawada et al. 1990, Kwan et al. 1991). Consequently, it has been suggested that otolin-1 is a prime candidate for development of the otolith framework (Murayama et al. 2002). It is, therefore, reasonable to hypothesize that the diel fluctuations in otolin-1 synthesis are manifested as the formation of daily increments. Immunohistochemical studies have also implicated otolin-1 in the formation of concentric ringlike depositions of the organic matrix in the trout otolith (Murayama et al. 2004).

Although immunohistochemical data suggest that cyclical deposition of OMP-1 occurs in the fish otolith (Murayama et al. 2004), expression of OMP-1 mRNA in this study did not exhibit marked diel changes. Using northern blot analysis, Murayama et al. (2000) also demonstrated that expression of OMP-1 mRNA did not exhibit any significant diurnal changes in the saccular tissues of the rainbow trout and chum salmon. Present experimental evidence does not, therefore, support the active involvement of OMP-1 in the formation of daily increments. Rather, the role of OMP-1 may be one involved in otolith calcification, since recombinant proteins of OMP-1 have the ability to interact with $\mathrm{CaCO}_{3}$ crystals (Murayama 2002). At present, the mechanism of the cyclical deposition observed in OMP-1 is unclear, and thus should be carefully examined in future.

The present study applied the method of Takagi (2002) to calculate the diel changes in the endolymph $S_{\mathrm{a}}$. It was found that endolymph was kept supersaturated with respect to aragonite during the day-night cycle. The diel fluctuations in $S_{\mathrm{a}}$ were small and insignificant, although endolymph levels of $\mathrm{Ca}^{2+}, \mathrm{pH}$ and $P_{\mathrm{CO}_{2}}$ showed significant diel variations. In such a supersaturated solution, calcium carbonate crystals can grow continuously in a non-biological system. These findings conflict with previously published reports in which clear diel fluctuations in Ca deposition into the otolith were observed (Mugiya et al. 1981, Mugiya 1984, 1987, Wright et al. 1992). The present data, therefore, strongly imply the involvement of an organic control mechanism in otolith calcification. Otolith matrix proteins probably have a crucial function in mediating or inhibiting aragonite deposition, and diel fluctuations in deposition of the matrix proteins lead to fluctuations in calcification. Although several reports have tried to explain the interaction between the otolith organic matrices and $\mathrm{Ca}^{2+}$ or $\mathrm{CaCO}_{3}$ (Baba et al. 1991, Wright 1991, Asano \& Mugiya 1992, Sasagawa \& Mugiya 1996, Borelli et al. 2001, Murayama 2002), the precise nature of the relationship between them remains unknown. In order to understand the mechanism of increment formation more accurately, we would have to clarify the function of each component of the organic matrices more precisely.

In assays of the proximal and distal zones of the sacculus in rainbow trout, Payan et al. (1999) demonstrated that the chemical composition of endolymph was not spatially uniform. While the endolymph used in the present study was a mixture of proximal and distal endolymph, its electrolyte composition was close to the values reported for distal endolymph by Payan et al. (1999). This may simply be a consequence of the much larger size of the distal space relative to the proximal space in the trout sacculus used in the present study, and the diel changes in the endolymph chemicals and saturation state reported here may thus be representative of the trout distal endolymph.

Borelli et al. (2003) sampled proximal and distal endolymph separately, estimated saturation states using total $\mathrm{Ca}, \mathrm{CO}_{2}$, protein levels and $\mathrm{pH}$, and compared the saturation states between day and night. Similar to the results of our study, the data obtained in their experiment suggested that the distal endolymph was supersaturated with respect to aragonite. In the proximal endolymph, however, the $S_{\text {a }}$ was in equilibrium (around 1.0), clearly lower than that observed in the distal zone. From this result, they suggested that otolith calcification in the proximal side only occurred when the 
$S_{\text {a }}$ exceeded 1.0. They proposed that the $\mathrm{pH}$ remained unchanged, and instead, that changes in $\mathrm{Ca}^{2+}$ and $\mathrm{CO}_{3}{ }^{2-}$ levels might lead to the changes observed in endolymph $S_{\mathrm{a}}$. These suggestions contrast markedly with the findings of this study that are representative of the distal endolymph. In the present study, endolymph was always supersaturated, and diel $S_{a}$ variations were small and insignificant. Moreover, $S_{\mathrm{a}}$ was largely determined by the $\mathrm{CO}_{3}{ }^{2-}$ levels that were dependent on $\mathrm{pH}$ levels, and variations in $\mathrm{Ca}^{2+}$ levels had insignificant effects on $S_{\mathrm{a}}$. At present, technical constraints mean that direct quantification of $S_{\mathrm{a}}$ in proximal endolymph is impossible. However, these constraints need to be overcome in the future so that the chemical composition and saturation state of the proximal endolymph can be quantified directly, and for the assumptions of Borelli et al. (2003) to be verified.

The present study demonstrated that changes in the concentrations of endolymph chemicals, except for $P_{\mathrm{CO}_{2}}$ levels, were independent of those in the plasma. This would suggest that the regulatory mechanisms for electrolyte transport are at the level of the saccular epithelium. Several previous studies have suggested the existence of energy-dependent electrolyte transport systems in the saccular epithelium. Mugiya \& Yoshida (1995) proposed a transcellular route for $\mathrm{Ca}^{2+}$ entry from plasma into the endolymph, involving a receptor-operated $\mathrm{Ca}^{2+}$ channel, a $\mathrm{Na}^{+} / \mathrm{Ca}^{2+}$ exchanger and a $\mathrm{Ca}^{2+}$-ATPase in the trout sacculus. Tohse \& Mugiya (2001) suggested that a $\mathrm{HCO}_{3}{ }^{-}$-ATPase and a $\mathrm{Cl}^{-} / \mathrm{HCO}_{3}{ }^{-}$exchanger are involved in the transepithelial transport of $\mathrm{HCO}_{3}{ }^{-}$to the endolymph in the sacculus of the masu salmon. Recently, Tohse \& Mugiya (2004) indicated that the metabolic inhibitor, cyanide, reduced the incorporation of $\mathrm{Ca}^{2+}$ and carbonate ions into the endolymph and otolith, suggesting that active transport mechanisms of both ions are found in the salmon sacculus. Conversely, Payan et al. (2002) studied the kinetic and pharmacological characteristics of $\mathrm{Ca}^{2+}$ fluxes across the saccular epithelium of the rainbow trout and suggested that endolymph, especially the proximal one, was supplied with $\mathrm{Ca}^{2+}$ in a concentration-gradient-dependent manner via a paracellular pathway. In the present study, the $\mathrm{Ca}^{2+}$ levels in the endolymph were not correlated with those of the plasma. In fact, variations in endolymph $\mathrm{Ca}^{2+}$ levels were smaller than those observed in the plasma, suggesting the strict control of endolymph $\mathrm{Ca}^{2+}$ levels. These data suggest the existence of regulatory mechanisms of $\mathrm{Ca}^{2+}$ transport into the endolymph, and thus support the idea of a transcellular pathway for $\mathrm{Ca}^{2+}$ entry, at least in the distal zone of the sacculus.

In conclusion, from the present results, we propose revision of a previous model to describe otolith growth and increment formation. The endolymph, at least in the distal zone, is kept supersaturated with respect to aragonite during the day-night cycle. On the other hand, some of the otolith matrix proteins are incorporated into the otolith in a diel, cyclical manner and regulate otolith growth, calcification and increment formation. Otolin-1, the synthesis of which is characterised by diel fluctuations at the level of mRNA expression, is the most likely candidate protein for increment formation.

Acknowledgements. The authors are grateful to Prof. E. Yamaha and Mr. S. Kimura, Nanae Freshwater Laboratory, Field Science Center for the Northern Biosphere at Hokkaido University, for their technical assistance and fish maintenance. This study was supported in part by the Grant-in-Aid for Creative Basic Research (No. 12N0201), for Scientific Research (Nos. 13660178 \& 15380125), and for the 21st Century COE Program, which are awarded by the Ministry of Education, Culture, Sports, Science and Technology, Japan.

\section{LITERATURE CITED}

Addadi L, Weiner S (1985) Interactions between acidic proteins and crystal: stereochemical requirements in biomineralization. Proc Natl Acad Sci USA 82:4110-4114

Asano M, Mugiya Y (1992) Biochemical and calcium-binding properties of water-soluble proteins isolated from otoliths of the tilapia, Oreochromis niloticus. Comp Biochem Physiol 104B:201-205

Baba K, Shimizu M, Mugiya Y, Yamada J (1991) Otolith matrix proteins of walleye pollock; biochemical properties and immunohistochemical localization in the saccular tissue. In: Suga S, Nakahara H (eds) Mechanisms and phylogeny of mineralization in biological systems. Springer-Verlag, Tokyo, p 57-61

Belcher AM, Wu XH, Christensen RJ, Hansma PK, Stucky GD, Morse DE (1996) Control of crystal phase switching and orientation by soluble mollusc-shell proteins. Nature 381:56-58

Borelli G, Mayer-Gostan N, De Pontual H, Boeuf G, Payan P (2001) Biochemical relationships between endolymph and otolith matrix in the trout (Oncorhynchus mykiss) and turbot (Psetta maxima). Calcif Tissue Int 69:356-364

Borelli G, Guibbolini ME, Mayer-Gostan N, Priouzeau F and 5 others (2003) Daily variations of endolymph composition: relationship with the otolith calcification process in trout. J Exp Biol 206:2685-2692

Campana SE (1999) Chemistry and composition of fish otoliths: pathways, mechanisms and applications. Mar Ecol Prog Ser 188:263-297

Campana SE, Neilson JD (1985) Microstructure of fish otoliths. Can J Fish Aquat Sci 42:1014-1032

Edeyer $A$, de Pontual $H$, Payan $P$, Troadec $H$, Sévère $A$, Mayer-Gostan N (2000) Daily variations of the saccular endolymph and plasma compositions in the turbot Psetta maxima: relationship with the diurnal rhythm in otolith formation. Mar Ecol Prog Ser 192:287-294

Enger PS (1964) Ionic composition of the cranial and labyrinthine fluids and saccular D.C. potentials in fish. Comp Biochem Physiol 11:131-137

Falini G, Albeck S, Weiner S, Addadi L (1996) Control of aragonite or calcite polymorphism by mollusk shell macromolecules. Science 271:67-69

Fänge R, Larsson Å, Lidman U (1972) Fluids and jellies of the acusticolateralis system in relation to body fluids in Coryphaenoides rupestris and other fishes. Mar Biol 17:180-185 
Gauldie RW, Romanek CR (1998) Orange roughy otolith growth rates: a direct experimental test of the RomanekGauldie otolith growth model. Comp Biochem Physiol 120A:649-653

Kalish JM (1991) Determinants of otolith chemistry: seasonal variation in the composition of blood plasma, endolymph and otoliths of bearded rock cod Pseudophycis barbatus. Mar Ecol Prog Ser 74:137-159

Kalish JM, Beamish RJ, Brothers EB, Casselman JM and 7 others (1995) Glossary for otolith studies. In: Secor DH, Dean JM, Campana SE (eds) Recent developments in fish otolith research. The University of South Carolina Press, Columbia, SC, p 723-729

Kwan APL, Cummings CE, Chapman JA, Grant ME (1991) Macromolecular organization of chicken type X collagen in vitro. J Cell Biol 114:597-604

Morales-Nin B (1987) Ultrastructure of organic and inorganic constituents of the otoliths of the sea bass. In: Summerfelt RC, Hall GE (eds) Age and growth of fish. Iowa State University Press, Ames, IA, p 331-343

Mugiya Y (1966) Calcification in fish and shell-fish - VI. Seasonal changes in calcium and magnesium concentrations of the otolith fluid in some fish, with special reference to the zone formation of their otolith. Bull Jpn Soc Sci Fish 32: $549-557$

Mugiya Y (1984) Diurnal rhythm in otolith formation in the rainbow trout, Salmo gairdneri: seasonal reversal of the rhythm in relation to plasma calcium concentrations Comp Biochem Physiol 78A:289-293

Mugiya Y (1987) Phase difference between calcification and organic matrix formation in the diurnal growth of otoliths in the rainbow trout, Salmo gairdneri. Fish Bull-NOAA 85: 395-401

Mugiya Y, Muramatsu J (1982) Time-marking methods for scanning electron microscopy in goldfish otoliths. Bull Jpn Soc Sci Fish 48:1225-1232

Mugiya Y, Takahashi K (1985) Chemical properties of the saccular endolymph in the rainbow trout, Salmo gairdneri. Bull Fac Fish Hokkaido Univ 36:57-63

Mugiya Y, Yoshida M (1995) Effects of antagonists and other metabolic modulators on in vitro calcium deposition on otoliths in the rainbow trout, Oncorhynchus mykiss. Fish Sci 61:1026-1030

Mugiya Y, Watabe N, Yamada J, Dean JM, Dunkelberger DG, Shimizu M (1981) Diurnal rhythm in otolith formation in the goldfish, Carassius auratus. Comp Biochem Physiol 68A:659-662

Murayama E (2002) Studies on the molecular mechanism of otolith formation in salmonids. $\mathrm{PhD}$ thesis, University of Tokyo

Murayama E, Okuno A, Ohira T, Takagi Y, Nagasawa H (2000) Molecular cloning and expression of an otolith matrix protein cDNA from the rainbow trout, Oncorhynchus mykiss. Comp Biochem Physiol 126B:511-520

Murayama E, Takagi Y, Ohira T, Davis JG, Greene MI, Nagasawa H (2002) Fish otolith contains a unique structural protein, otolin-1. Eur J Biochem 269:688-696

Murayama E, Takagi Y, Nagasawa H (2004) Immunohistochemical localization of two otolith matrix proteins in the otolith and inner ear of the rainbow trout, Oncorhynchus mykiss: comparative aspects between the adult inner ear and embryonic otocysts. Histochem Cell Biol 121:155-166

Pannella G (1971) Fish otoliths: daily growth layers and periodical patterns. Science 173:1124-1127

Payan P, Kossmann H, Watrin A, Mayer-Gostan N, Boeuf G (1997) Ionic composition of endolymph in teleosts: origin and importance of endolymph alkalinity. J Exp Biol 200: 1905-1912

Editorial responsibility: Otto Kinne (Editor-in-Chief), Oldendorf/Luhe, Germany
Payan P, Borelli G, Boeuf G, Mayer-Gostan N (1998) Relationship between otolith and somatic growth: consequence of starvation on acid-base balance in plasma and endolymph in the rainbow trout Oncorhynchus mykiss. Fish Physiol Biochem 19:35-41

Payan P, Edeyer A, de Pontual H, Borelli G, Boeuf G, MayerGostan N (1999) Chemical composition of saccular endolymph and otolith in fish inner ear: lack of spatial uniformity. Am J Physiol 277:R123-R131

Payan P, Borelli G, Priouzeau F, De Pontual H, Boeuf G, Mayer-Gostan N (2002) Otolith growth in trout Oncorhynchus mykiss: supply of $\mathrm{Ca}^{2+}$ and $\mathrm{Sr}^{2+}$ to the saccular endolymph. J Exp Biol 205:2687-2695

Romanek CS, Morse JW, Grossman EL (1991) Aragonite precipitation kinetics in dilute solutions: temperature effects. Geological Society America, Program with Abstracts 23:A151

Sasagawa T, Mugiya Y (1996) Biochemical properties of water-soluble otolith proteins and the immunobiochemical detection of the proteins in serum and various tissues in the tilapia Oreochromis niloticus. Fish Sci 62:970-976

Sawada H, Konomi H, Hirosawa K (1990) Characterization of the collagen in the hexagonal lattice of Descemet's membrane: its relation to type VIII collagen. J Cell Biol 110:219-227

Takagi Y (1997) Meshwork arrangement of mitochondriarich, $\mathrm{Na}^{+}, \mathrm{K}^{+}$-ATPase-rich cells in the saccular epithelium of rainbow trout (Oncorhynchus mykiss) inner ear. Anat Rec 248:483-489

Takagi Y (2000) Ultrastructural immunolocalization of the otolith water-soluble-matrix in the inner ear of rainbow trout just-hatched fry. Fish Sci 66:71-77

Takagi Y (2002) Otolith formation and endolymph chemistry: a strong correlation between the aragonite saturation state and $\mathrm{pH}$ in the endolymph of the trout otolith organ. Mar Ecol Prog Ser 231:237-245

Takagi Y, Takahashi A (1999) Characterization of otolith soluble-matrix producing cells in the saccular epithelium of rainbow trout (Oncorhynchus mykiss) inner ear. Anat Rec 254:322-329

Takagi Y, Ishida K, Mugiya Y (2000) Carbohydrates of the otolith organ in the rainbow trout Oncorhynchus mykiss detected by lectins. Fish Sci 66:933-939

Tohse H, Mugiya Y (2001) Effects of enzyme and anion transport inhibitors on in vitro incorporation of inorganic carbon and calcium into endolymph and otoliths in salmon Oncorhynchus masou. Comp Biochem Physiol A 128:177-184

Tohse H, Mugiya Y (2002) Diel variations in carbonate incorporation into otoliths in goldfish. J Fish Biol 61:199-206

Tohse H, Mugiya Y (2004) Effects of acidity and a metabolic inhibitor on incorporation of calcium and inorganic carbon into endolymph and otoliths in salmon Oncorhynchus masou. Fish Sci 70:595-600

Watabe N, Tanaka K, Yamada J, Dean JM (1982) Scanning electron microscope observations of the organic matrix in the otolith of the teleost fish Fundulus heterocritus (Linnaeus) and Tilapia nilotica (Linnaeus). J Exp Mar Biol Ecol 58:127-134

Watanabe Y, Miyamoto H (1973) Biochemical study of labyrinthine fluids (of the fish). Med J Osaka Univ 23: 273-282

Wheeler AP, Sikes CS (1984) Regulation of carbonate calcification by organic matrix. Am Zool 24:933-944

Wright PJ (1991) Calcium binding by soluble matrix of the otoliths of Atlantic salmon, Salmo salar L. J Fish Biol 38: 625-627

Wright PJ, Talbot C, Thorpe JE (1992) Otolith calcification in Atlantic salmon parr, Salmo salar L. and its relation to photoperiod and calcium metabolism. J Fish Biol 40:779-790

Submitted: July 27, 2004; Accepted: February 8, 2005

Proofs received from author(s): May 18, 2005 